THE YALE LAW JOURNAL FORUM

JUNE 1, 2016

\title{
Democracy and Legitimacy in Investor-State Arbitration
}

\author{
Cory Adkins \& David Singh Grewal
}

In January 2016, the Canadian infrastructure company TransCanada Corporation filed a notice of intent to sue the United States government in a North American Free Trade Agreement (NAFTA) Chapter 11 arbitration over the Keystone XL pipeline. ${ }^{1}$ At the center of this dispute is the State Department's refusal to permit the construction of an oil pipeline between Canada and Nebraska. TransCanada claims that the State Department ignored its own favorable environmental assessments of the pipeline multiple times and rejected the proposal to placate misinformed activists and foreign governments. ${ }^{2}$ The State Department acknowledges that it denied the permit to enhance the Obama Administration's credibility at the 2015 United Nations Climate Change Conference in Paris, with the long-term goal of reducing emissions through collective political action. ${ }^{3}$

This Essay situates the TransCanada arbitration within the history of investment arbitration, highlighting recent collisions between arbitral regimes and the modern regulatory state. After briefly discussing the history of investment arbitration, we discuss in depth the collision's most startling fallout so far-the Clayton $v$. Canada award on liability. Finally, we suggest how the TransCanada tribunal should view the Clayton award.

1. Notice of Intent To Submit a Claim to Arbitration Under Chapter 11 of the North American Free Trade Agreement, TRANSCANADA CORP. (Jan. 6, 2016), http://www.keystone-xl.com/wp-content/uploads/2016/o1/TransCanada-Notice-of-Intent -January-6-2016.pdf [http://perma.cc/2WUT-LY4S] [hereinafter Notice] (Chapter 11 is NAFTA's investment chapter, which provides rights and remedies for investors in NAFTA countries; it represents the first major merger of an investment agreement with a free trade area).

2. Id. 947 .

3. Dep'T of State, Record of Decision and National Interest Determination: Transcanada Keystone Pipeline, L.P. ApPlication for Presidential Permit (2015), http://keystonepipeline-xl.state.gov/documents/organization/24945o.pdf [http://perma.cc /KKE5-TNZV]. 
The current litigation over the Keystone pipeline must be situated within the longer history of investment arbitration. Investment arbitration previously governed relations between investors from capital-exporting, developed democracies and governments of developing, mainly post-colonial countries. ${ }^{4}$ A cousin of "diplomatic protection," it was first used to protect colonial investments in the eighteenth and nineteenth centuries. ${ }^{5}$ After the decolonization of the twentieth century, investment arbitration became a tool of economic development for the newly christened "developing world": foreign capital was believed to need special protection in order to flow into areas subject to ongoing economic and political uncertainty. ${ }^{6}$ Bilateral investment treaties-the state-to-state agreements permitting investor-to-state arbitration - sought to establish minimally fair and equitable treatment for investments in countries where self-dealing autocrats might seize all of a foreign investor's property or ruling nationalist parties might view investment from abroad with hostility in the context of recently concluded anticolonial struggles. But beginning in the 1960 s, both the United Nations and the World Bank established rules and institutions to administer standardized investment arbitrations. While these were initially focused on the developing world, the mechanism gradually came into more general use. ${ }^{7}$ As this new form of legality spread, even developed states with sophisticated judicial systems found themselves defending against claims of investment expropriation. ${ }^{8}$

The result is that developed democracies are now being targeted under a system of arbitration they had designed for use elsewhere. The translation of

4. For example, the first bilateral investment treaty with investor-state dispute settlement (ISDS) was the Treaty for the Promotion and Protection of Investments, Ger.-Pak., art. 11, I 2, Nov. 25, 1959, 457 U.N.T.S. 24 (entered into force Nov. 28, 1962).

5. Andrew Newcomb \& Lluís Paradell, LaW and Practice of Investment Treaties $\$ 1.5$ (2009). Diplomatic protection differs crucially from investor-state dispute resolution in that diplomatic protection involved states bringing claims on behalf of their injured nationals. Investment arbitration may represent a delegation of this power to the injured nationals, thereby privatizing this aspect of foreign relations, or a coexisting remedial scheme. See Anthea Roberts, State-to-State Investment Treaty Arbitration: A Hybrid Theory of Independent Rights and Shared Interpretive Authority, 55 HARV. INT'L. L.J. 1, 1-3 (2014); cf. Opinion with Respect to Jurisdiction of W. Michael Reisman, Ecuador v. United States, Case No. 2012-05, 20-21 (Perm. Ct. Arb. Apr. 24, 2012), http://pcacases.com/web/sendAttach $/ 582$ [http://perma.cc/8KMU-6Z5G] (arguing for a "two-track" regime with sovereign-tosovereign and investor-state dispute settlement).

6. See Mattias Kumm, An Empire of Capital? Transatlantic Investment Protection as the Institutionalization of Unjustified Privilege, 4 EUR. SOC'Y INT'L L. REFLECTIONS 1, 2-4 (2015).

7. In the past few decades, the number of bilateral investment treaties has exploded, increasing from 457 in 1990 to 2,926 at the time of publication. See International Investment Agreements Navigator (Advanced Search), United Nations Conf. ON Trade \& Dev., http://investmentpolicyhub.unctad.org/IIA [http://perma.cc/6G9P-5Y9X].

8. For a fuller discussion of this reversal, see Anthea Roberts, Triangular Treaties: The Extent and Limits of Investment Treaty Rights, 56 HARV. INT'L L.J. 353, 358-62 (2015). 
the old investment arbitration paradigm into one that enables lawsuits against the governments of developed countries has dramatically changed the arbitral landscape. Under the current dispensation, corporations headquartered in stable, liberal democracies bring claims against the regulatory policies of other stable, liberal democracies using the court systems of neither. For instance, either the United States or Canada has been the target in fifty-eight out of eighty-one NAFTA Chapter 11 investment arbitrations in twenty-two years, and the opposing party is usually a U.S. or Canadian corporation. ${ }^{9}$ Australia only recently saw the end of a long-running dispute with Philip Morris over a public health measure that the tobacco company deemed an expropriation. ${ }^{10}$ Claims of this kind will likely increase in the future: the controversial TransPacific Partnership, if passed, will double the number of investors who can bring suit against the United States. ${ }^{11}$

As investment arbitration has grown to encompass both developing countries and developed democracies, the scope of review has expanded. Where arbitration tribunals originally focused on outright expropriation of private investments, they are increasingly called upon to review regulatory actions that negatively impact the profits of foreign investors. ${ }^{12}$ Recent cases have concerned new environmental measures, ${ }^{13}$ the regulation of nuclear power, ${ }^{14}$ changes to fiscal regimes ${ }^{15}$ the scope of patent protection for

9. Table of Foreign Investor-State Cases and Claims Under NAFTA and Other U.S. "Trade" Deals, Pub. CITIZEN (June 2015), http://www.citizen.org/documents/investor-state-chart.pdf [http://perma.cc/ $\left.\mathrm{M}_{5} \mathrm{YC}-7 \mathrm{CX}_{3}\right]$.

10. Phillip Morris Asia Ltd. v. Australia, Case No. 2012-12, Award on Jurisdiction and Admissibility (Perm. Ct. Arb. 2015), http://www.italaw.com/sites/default/files /case-documents/italaw73o3_o.pdf [http://perma.cc/Y4TX-VQR4]. The decision will be published pending redaction of confidential information.

11. Lise Johnson, Lisa Sachs \& Jeffrey Sachs, Investor-State Dispute Settlement, Public Interest and U.S. Domestic Law, COLUM. CTR. ON SUSTAINABLE INV. 5 (May 2015), http://ccsi.columbia.edu/files/2015/o5/Investor-State-Dispute-Settlement -Public-Interest-and-U.S.-Domestic-Law-FINAL-May-19-8.pdf $\quad[\mathrm{http}: / /$ perma.cc/3DZ6 -AGDA].

12. Id. at 2-3; see also cases cited infra notes $13-17$.

13. Glamis Gold, Ltd. v. United States, Award (NAFTA Ch. 11 Arb. Trib. 2009), http:// www.state.gov/documents/organization/125798.pdf [http://perma.cc/QDW3-GKZR]; Lone Pine Res. Inc. v. Gov't of Can., ICSID Case No. UNCT/15/2, Claimant's Memorial (Apr. 1o, 2015), http://icsid.worldbank.org/ICSID/FrontServlet?requestType=CasesRH\&actionVal =showDoc\&docId=DC5878_En\&caseId=C4406 [http://perma.cc/7HFD-NGBA].

14. Vattenfall $A B$ v. Fed. Republic of Ger., ICSID Case No. ARB/og/6, Award (Mar. 11, 2011), http://www.italaw.com/sites/default/files/case-documents/itao89o.pdf [http://perma.cc/K32R-PZ25].

15. Occidental Petroleum Corp. v. Republic of Ecuador, ICSID Case No. ARB/o6/11, Award (Oct. 5, 2012), http:/icsid.worldbank.org/ICSID/FrontServlet?requestType =CasesRH\&actionVal=showDoc\&docId=DC2672_En\&caseId=C8o [http://perma.cc/3KUA -VA8G]. 
pharmaceuticals, ${ }^{16}$ and the restructuring of sovereign debt. ${ }^{17}$ While plaintiffs in domestic eminent domain and "regulatory takings" cases have very low success rates of around four percent, ${ }^{18}$ complainants in arbitrations of expropriation and indirect claims have success rates around forty percent. ${ }^{19}$

As the scope of investment arbitration has expanded, so has the conception of the "minimum standard of treatment" by which government actions are judged. In the context of NAFTA arbitrations - in which the litigation over the Keystone XL pipeline will be decided-this shift has been highlighted in a recently concluded dispute, Clayton $v$. Canada. ${ }^{20}$ The Clayton Award makes apparent the deficit of legitimacy when an ad hoc, international arbitral panel evaluates the conformity of a country's domestic laws with its treaty obligations. Interestingly, while the majority decision arguably undermines Canadian sovereignty, its language pays constant tribute to the Canadian people's power to make and pass laws consistent with its values. Clayton is thus not a caricature of neoliberal jurisprudence ${ }^{21}$ : the Award did not simply deny Canada's power to make laws that interfere with expectations of corporate profit. Instead, it was anxious to accommodate democratic sovereignty at every step. But, we argue below, it failed to do so when it abandoned its commitment to democratic sovereignty in the application of several review standards to the facts. ${ }^{22}$ Clayton thus shows investment arbitration at an impasse: divided between a minimalist conception in which it merely serves as a buffer for multinational corporations against corrupt government officials, and an expanded role in which it becomes a forum for the recognition of foreign

16. Eli Lilly \& Co. v. Gov't of Can., ICSID Case No. UNCT/14/2, Claimant's Memorial (Sept. 29, 2014), http://icsid.worldbank.org/ICSID/FrontServlet?requestType $=$ CasesRH\&actionVal=showDoc\&docId $=$ DC4983_En\&caseId $=C_{3544} \quad[$ http: $/ /$ perma.cc /MX8W-XTK7].

17. Abaclat et al. v. Argentine Republic, ICSID Case No. ARB o7/5, Decision on Admissibility and Jurisdiction, ๆ 8 -10 (Aug. 4, 2011), http://www.italaw.com/sites/default/files/case -documents/itao236.pdf [http://perma.cc/2MUD-XPG5].

18. Adam R. Pomeroy, Penn Central After 35 Years: A Three Part Balancing Test or a One Strike Rule, 22 Fed CIR. B.J. 677, 698 (2012).

19. See Susan D. Franck, The ICSID Effect? Considering Potential Variations in Arbitration Awards, 51 VA. J. INT'L L. 825, 852 (2011). The comparison between domestic regulatory takings and expropriation is a rough one, given the different contexts.

2o. See, e.g., Clayton v. Government of Canada, Award on Jurisdiction and Liability, Case No. 2009-04, ๆๆ 601-602 (Perm. Ct. Arb. 2015), http://www.pcacases.com/web/sendAttach /1287 [http://perma.cc/WXB8-WL89] [hereinafter Award].

21. For an analysis of neoliberalism in its legal aspects, see David Singh Grewal \& Jedediah Purdy, Introduction: Law and Neoliberalism, 77 LAW \& CONTEMP. Probs. 1-23, 2 (2015) ("Neoliberalism is an overlapping set of arguments and premises ... that are united by their tendency to support market imperatives and unequal economic power in the context of political conflicts that are characteristic of the present historical moment.")

22. See infra discussion accompanying notes $33-42$. 
interests in the review of domestic laws. ${ }^{23}$ In the Essay's final section, we argue that the TransCanada tribunal should reject the latter approach.

The Clayton claims centered on a proposal for a marine quarry in Nova Scotia that Canadian environmental assessors found could not proceed without causing irreparable damage to the land, marine, and human environments in the Digby Neck and Whites Point areas, including the local fishing and aboriginal populations. ${ }^{24}$ Technically, the Clayton family claimed that Canada had violated three different NAFTA provisions: the Article 1105 guarantee of fair and equitable treatment for foreign investors, the Article 1102 guarantee of treatment no worse than Canadian investors ("national treatment"), and the Article 1103 guarantee of treatment no worse than investors from any other nation ("most favored nation"). In a contentious 2-1 decision, the tribunal found that Canada had breached its NAFTA commitments by failing to treat the corporate complainant-Bilcon of Delaware, Inc., owned by the Clayton family-fairly, equitably, and consistently with other corporations. Put simply, a majority of the tribunal held the Canadian government liable for having a different view of Canadian law than the arbitrators themselves. ${ }^{25}$

The Clayton Award represents the high water mark of the new investment arbitration: with Bilcon asking for as much as $\$ 300$ million, the judgment for the corporate complainant could be the largest monetary award granted to any complainant in the history of Chapter 11 arbitrations when the tribunal eventually issues an award on damages. ${ }^{26}$ Although the case involved three claims - under Articles 1102, 1103, and 1105-they all essentially turned on one determination: whether the Canadian joint review panel (JRP) could consider "community core values" in its report, and whether such considerations could be the basis for rejecting a project whose effects on the non-human environment were potentially mitigatable. ${ }^{27}$ If so, then Canada merely followed its own law-consistent with the investors' expectations that the project must "comply with federal and provincial laws concerning the environment" 28 which would satisfy the requirement of fair, equitable, and non-differential treatment. But if the JRP could not properly consider community values, then

23. See Kumm, supra note 6 , at 6 .

24. Clayton v. Government of Canada, Case No. 2009-04, Dissenting Opinion of Professor Donald McRae, qฯ 22-26 (Perm. Ct. Arb. 2015), http://www.pcacases.com/web /sendAttach/1288 [http://perma.cc/N68F-95EF] [hereinafter Dissent].

25. See id. ๆ $34-35$.

26. John DeMings, Bilcon Wins NAFTA Dispute Over Digby Neck Quarry, DIGBY CoUnTY COURIER (Mar. 21, 2015), http://www.digbycourier.ca/News/Regional/2015-03-21/article -4085504/Bilcon-wins-NAFTA-dispute-over-Digby-Neck-quarry/1 [http://perma.cc/QSU5 -JJWX]. The Clayton tribunal has not yet rendered a damages award.

27. See Award, supra note $20,9323$.

28. Id. 9589 . 
its conduct might represent an Article 1105 violation if it could be deemed "grossly unfair, unjust, or idiosyncratic" or would "lead . . . to an outcome which offends judicial propriety." 29 Such a violation could also qualify as a most-favored nation and national treatment violation: Canada cannot treat foreign corporations grossly unjustly when it has not subjected domestic corporations to the same injustices - which, arguably, it had not done, since it was the novel application of the law that created the gross injustice in the first analysis. ${ }^{30}$

It is true that a variety of state actions do not rise to the level of "grossly unfair, unjust, or idiosyncratic" or otherwise "offend[] judicial propriety," but these actions might nevertheless give rise to colorable claims of liability against the state. ${ }^{31}$ A line of NAFTA Chapter 11 cases - and even Clayton itself-go to great lengths to recognize that actions within this range do not count as violations of Article 1105. Article 1105 only imposes a "minimum standard of treatment," independent of any particular national laws..$^{32}$ Otherwise, state actions subject to any potential legal challenge could become a boon to foreign investors, who would exclusively enjoy the benefits of this relaxed legal standard. The Clayton Award was unusual in that it disregarded previously established NAFTA Chapter 11 practices of distinguishing between a state's outright expropriation of an investor's property, a state's mere unlawful conduct, and a state's following a reasonable view of its own laws. Absent these distinctions, the arbitral tribunal-whose judgment cannot be appealed in U.S. or Canadian courts ${ }^{33}$ - becomes, in effect, a national court of last resort with jurisdiction over not only questions of egregious deviations from international standards of fair treatment, but also proper interpretations of domestic law. ${ }^{34}$

29. Id. T 400 (quoting Mobil Investments Canada Inc. v. Canada, ICSID Case No. ARB (AF)/o7/o4, Decision on Liability and on Principles of Quantum, 9 152-53 (May 22, 2012)).

30. Id. ๆ 715. (" $[\mathrm{T}]$ he emphasis on 'community core values' raises the serious question of whether the project would have received more favorable treatment if the investor had not been foreign.").

31. Id. ๆ 400 (quoting Mobil Investments Canada Inc. v. Canada, ICSID Case No. $\mathrm{ARB}(\mathrm{AF}) / 07 / 04$, Decision on Liability and on Principles of Quantum, ๆ 152-53 (May 22, 2012)).

32. Waste Management, Inc. v. Mexico, ICSID Case No. ARB(AF)/oo/3, Award, qฯ 98-99 (Apr. 3o, 2004), http://www.italaw.com/sites/default/files/case-documents/itaogoo.pdf [http://perma.cc/4AFS-DAYV] [hereinafter Waste Management]. Here the Clayton tribunal, operating under the UNCITRAL rules, cited to an award under ICSID rules. Such crosspollination is not uncommon.

33. Awards under the UNCITRAL rules-like Clayton-can be set aside under certain circumstances. Awards under the ICSID rules-like TransCanada will be-can be set aside only under very limited circumstances.

34. See Letter from Judith Resnik, Professor of Law, Yale Law Sch., et al., to Mitch McConnell, Senate Majority Leader, U.S. Congress (Apr. 
In the Clayton dispute, the laws in question concerned the JRP's administrative prerogatives; in the coming TransCanada litigation, they might even require an assessment of the President's constitutional authority. ${ }^{35}$

Even as the Clayton majority collapsed the distinction between arguable violations of domestic law and violations of the independently established minimum standard specific to foreign investor-state relationships, it reiterated the concerns that had motivated the distinction between these two standards in the first place. Indeed, the Award forcefully defended the sovereignty of Canadian lawmakers in principle:

Lawmakers in Canada . . . can set environmental standards as demanding and broad as they wish and can vest in various administrative bodies whatever mandates they wish. Errors, even substantial errors, in applying national laws do not generally . . . rise to the level of international responsibility vis-à-vis foreign investors. ${ }^{36}$

To use investment arbitration to attack such policies would be an affront to the legitimate lawmaking process: investor arbitration, the tribunal explained, is "not supposed to be the continuation of domestic politics and litigation by other means." ${ }^{37}$ One implication of these commitments is to allow administrative agencies the discretion to make factual and evaluative decisions consistent with the statutory regime. As the Clayton majority put it directly:

Modern regulatory and social welfare states tackle complex problems. Not all situations can be addressed in advance by the laws that are enacted. Room must be left for judgment to be used to interpret legal standards and apply them to the facts .... [W] hen state officials are acting in good faith there will sometimes be not only controversial judgments, but clear-cut mistakes in following procedures .... [This] imprudent exercise of discretion or even outright mistake do [es] not, as a rule, lead to a breach of the international minimum standard. ${ }^{38}$

Accordingly, Clayton_attempted to follow the interpretation of NAFTA Article 1105 developed in a previous arbitration, Waste Management. ${ }^{39}$ Under the Waste Management standard, the "minimum standard of fair and equitable treatment is infringed by conduct... [that] is arbitrary, grossly unfair, unjust

3o, 2015), http://www.washingtonpost.com/r/2010-2019/WashingtonPost $/ 2015 / 04 / 30$ /Editorial-Opinion/Graphics/oppose_ISDS_Letter.pdf [http://perma.cc/5XZU-Z22L].

35. See infra discussion accompanying notes 53-58.

36. Award, supra note 20,9738 (emphasis added).

37. Id. ๆ 437 .

38. Id. (emphasis added).

39. See id. ๆ $442-43$. 
or idiosyncratic ... or involves a lack of due process leading to an outcome which offends judicial propriety." ${ }^{\circ 0}$ This standard is more lenient than those adopted by previous NAFTA tribunals, which have traditionally required "egregious" and "outrageous" state action. ${ }^{41}$ But it is still a strict standard, requiring more than a possible violation of domestic law.

When the Clayton majority applied the Waste Management standard to the facts of the dispute, it did so in a manner that defeated its self-proclaimed respect for domestic sovereignty. The majority declared the JRP findings "arbitrary" because the review panel had not conducted a "likely significant adverse effects after mitigation" analysis, under which potential mitigation of a project's environmental effects might save an otherwise rejected project. ${ }^{42}$ The JRP had declined to do so because the proposed project's effects on the human environment -including on the local fishing and aboriginal populations, which did not meet with any representatives of Bilcon ${ }^{43}$ - were deemed too extreme. In arriving at its decision, the Clayton majority abandoned the other language from Waste Management (i.e. "grossly unfair") and interpreted "arbitrary" as a mere possible violation of Canadian law. ${ }^{44}$ Indeed, the Award "simply holds that the applicant was not treated in a manner consistent with Canada's own laws" 45 on the basis of two arbitrators' interpretation of Canadian law. This forms the sole basis for a finding of an Article 1105 violation.

It remains far from obvious whether Canada's environmental assessment statutes require review panels to report on potential mitigation measures, especially when a project's impact on the human environment cannot be mitigated. The statutes authorizing the review - the Canadian Environmental Assessment Act and Nova Scotia Environments Act-both explicitly authorize the consideration of effects on the human environment, including on the current use of land by indigenous groups. ${ }^{46}$ The Canadian Environmental Assessment Act requires an evaluation, by a minister or review panel, of the environmental effects of a somewhat narrow class of construction and infrastructure projects with connections to the federal government. ${ }^{47}$ The Act instructs the panel to consider as environmental effects "any change...on (i) health and socio-economic conditions, (ii) physical and cultural heritage, (iii) the

\footnotetext{
40. Waste Management, supra note $32,998$.

41. Award, supra note $20,9936,434$.

42. Id. ๆ 591 .

43. Dissent, supra note $24,925$.

44. Award, supra note $20,9602$.

45. Id.

46. Nova SCOTIA ENV'T Act, S.N.S. 1994-5, c.1, sec. (3)(v)(i).

47. Canadian Envt'L. Assessment ACt, S.C. 1992, c. 37.
} 
current use of lands and resources for traditional purposes by aboriginal persons." ${ }^{48}$ The Nova Scotia Environments Act uses the same language. Although the Clayton Award cited some of this statutory language, it never addressed why that language clearly prohibits the conclusion that effects on the human environment may preclude the possibility of mitigating non-human environmental degradation. The majority instead simply argued that since no review panel had previously used a similar strategy, the panel's decision could not be consistent with investors' legitimate expectations. ${ }^{49}$

The Clayton Award will be welcomed by investors who may now claim breaches of laws not yet fully specified by Canadian courts or who allege that Canadian law does not meet an international minimum standard of treatment. However, the Award is inconsistent with the principled respect for democratic sovereignty with which the majority began its analysis. At the conceptual level, the Award claims to uphold the importance of democratic control over national laws, but it strips this commitment of meaning in its actual application to the facts. It seeks to serve two inconsistent goals: upholding a conception of investment arbitration as providing minimal fairness, consistent with democratic sovereignty, and carving out a special privilege for foreign investors to use what may prove favorable versions of domestic law.

The Clayton majority functionally pursued the latter aim despite its forthright anxiety about its own democratic legitimacy. Unlike the majority, the impassioned dissent in Clayton recognized the true significance of the tribunal's approach: the decision presented "a significant intrusion into domestic jurisdiction" and would "chill" Canadian administrative law. ${ }^{50}$ It put the "proper application of Canadian law by an environmental review panel . . . in[to] the hands of a NAFTA Chapter 11 tribunal, importing a damages remedy that is not available under Canadian law." ${ }^{11}$ By expanding a damages remedy available only to foreign corporate litigants in privatized litigation, the Clayton Award has confirmed the fear that special investor-state dispute

48. Id. at sec. 2. (emphasis added). Likewise, when Lee Clark, Member of Parliament and Parliamentary Secretary to the Minister of the Environment, introduced the bill in Parliamentary debate in 1992, he emphasized the bill's broad coverage: it would "make environmental factors equal partners . . . with social and economic concerns." House of Commons Debates, 34th Parl., 3rd Sess., vol. 7, at 8373 (Mar. 17, 1992) (statement of Lee Clark, Member, Parliament) (emphasis added), http://parl.canadiana.ca/view/oop .debates_HOC3403_07/299?r=o\&s=1 [http://perma.cc/VQ6E-SKQL].

49. See, e.g., Award, supra note $20,9573$.

50. Dissent, supra note 24,948 .

51. Id. 
mechanisms can undermine democracy and the rule of law. ${ }^{52}$ Ironically, it does so in spite of the majority's robust rhetorical support for these very principles.

Clayton has significant parallels with the TransCanada litigation. Both involve the denial of a permit for a large infrastructure project by an administrative agency that determined that the project passed particular quantitative environmental impact tests but nonetheless had to be rejected on other policy grounds. Like the use of "community core values" by the JRP in Clayton, the State Department's use of the U.N. Climate Change talks to justify the Keystone XL permit denial is unique, but far from unforeseeable. The relevant Executive Order grants the State Department broad authority to deny permits not in the "national interest." ${ }^{53}$ Moreover, the State Department's role in the U.S. government provides a substantial clue that its view of the "national interest" might include managing foreign relations to enable global collective action on climate change.

As in Clayton, the TransCanada arbitration will turn on whether the United States violated Articles 1102, 1103, 1105 and 1110 of NAFTA, which promise non-discrimination, fair and equitable treatment, and compensation for expropriation to Canadian investors by the United States. In support of these claims, TransCanada's Notice of Intent alleges that the State Department unjustifiably delayed its review of the pipeline, and implies that it exceeded the authority delegated by the President. ${ }^{54}$ Although we do not know exactly what arguments TransCanada will make to the arbitral tribunal, the corporation has revealed its likely strategy in a parallel civil complaint filed in the Southern District of Texas. ${ }^{55}$ That strategy shares the conceptual commitments of the Clayton tribunal in seeking to base a NAFTA violation on a precise interpretation of a broad domestic legal rule-in this case, the U.S. Constitution. In its civil complaint, TransCanada argues that the State Department's permit denial is an unconstitutional assertion of executive power, and therefore violates NAFTA obligations. Drawing on Justice Jackson's legendary concurrence in Youngstown Steel, TransCanada argues that President Obama has acted at the "lowest ebb" of his power by denying a permit for a pipeline that Congress itself tried to authorize in 2014 before being stymied by

52. New developments may bring ISDS in line with democratic values. See, for example, the Comprehensive Economics and Trade Agreement, 8.18(2), which limits ISDS claims to "existing business operations of a covered investment."

53. See Exec. Order No. 13,337, 69 Fed. Reg. 25,299 (May 5, 2004).

54. Notice, supra note 1 , 9 91-60.

55. TransCanada Keystone Pipeline, LP v. John Kerry, Complaint, Case 4:16-cv-ooo36 (S.D. Tex. filed Jan. 6, 2016) [hereinafter Complaint]. That TransCanada has chosen to file an additional civil claim in U.S. District Court casts some doubt on the premise of investment arbitration-that domestic courts cannot be trusted to treat foreign investors fairly. See David Schneiderman, Listening to Investors (and Others): Audi Alteram Partem and the Future of International Investment Law (unpublished article) (on file with authors). 
a presidential veto. ${ }^{56}$ In the company's view, this allegedly unconstitutional exercise of presidential power is tantamount to a NAFTA violation. In the alternative, TransCanada argues that the State Department exceeded any authority that the President has or could have delegated. ${ }^{57}$ As the civil complaint summarizes, "given the unprecedented basis for and nature of the denial of the Presidential Permit for construction and operation of the Keystone XL Pipeline, the denial is arbitrary and frustrated plaintiffs' legitimate investment expectations." ${ }^{8}$

To those readers unfamiliar with the operation of investor-state arbitration, it may seem strange to charge an ad hoc tribunal with deciding the legality of the State Department's actions under the U.S. Constitution or an Executive Order. But TransCanada can point to a growing body of investment arbitration awards that base violations of investors' legitimate expectations on interpretations of domestic law. By making a constitutional argument, TransCanada seeks to focus the tribunal on an exercise of constitutional interpretation, rather than on the State Department's broad and well-known power to reject permits inconsistent with the "national interest," 59 or on the obvious risk that the pipeline would be rejected on other grounds.

The use of ad hoc tribunals to judge constitutional matters appears to be the unfortunate next step in an increasingly intrusive jurisprudence of investment arbitration. Instead of deepening the mistake made in Clayton, we believe the tribunal considering the Keystone XL litigation should hew to the spirit of older NAFTA Chapter 11 cases in deciding the Article 1105 fair and equitable treatment claim. ${ }^{60}$ The tribunal should ask itself whether the State Department's denial of the permit was egregious, outrageous, or completely unforeseeable. This is the relevant question, and no answer should assume that states must rely only on policy considerations that have already been fully and formally elaborated in domestic statutes and legal decisions. ${ }^{61}$ Such an assumption would limit states to using yesterday's solutions for tomorrow's problems. By declining to go down that route, the TransCanada tribunal can resurrect the deference to democracy given merely rhetorical effect in Clayton.

56. Complaint, supra note $55,969$.

57. Id. ๆ 93-122.

58. Id. ๆ 81.

59. Exec. Order No. 13,337, 69 Fed. Reg. 25,299 (May 5, 2004).

6o. Strategic considerations, like the desire to legitimate ISDS to Canadians or Americans during the course of treaty negotiations, may influence the tribunal in either direction. See David Schneiderman, Judicial Politics and International Investment Arbitration: Seeking an Explanation for Conflicting Outcomes, 3o NW. J. INT'L L. \& BUS. 383, 404-o6 (2010).

61. Cf. Saluka Inv. BV (Neth.) v. Czech Republic, Partial Award, ๆ 305 (UNCITRAL 2006) ("No investor may reasonably expect that the circumstances prevailing at the time the investment is made remain totally unchanged."). 
The authors are, respectively, J.D. Candidate, Yale Law School, and Associate Professor of Law, Yale Law School. They are grateful to Johanna Lorenzo, Murilo Lubambo, Georgios Dimitropoulos, and David Schneiderman for comments and criticisms.

Preferred Citation: Cory Adkins \& David Grewal, Democracy and Legitmacy in Investor-State Arbitration, 126 YALE L.J. F. 65 (2016), http://www.yalelawjournal.org/forum/democracy-and-legitimacy-in-investorstate-arbitration. 